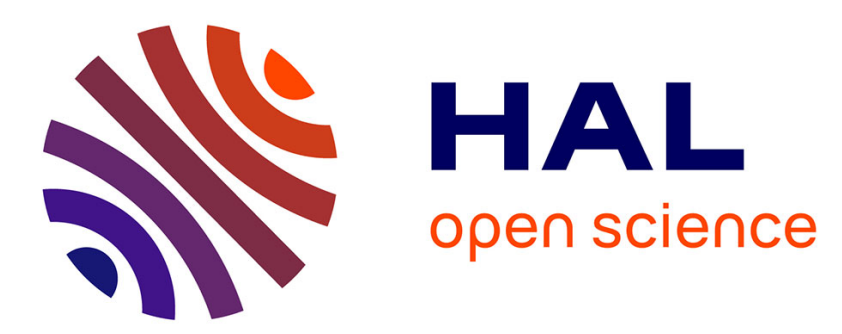

\title{
Healthy and unhealthy migrant effect on the mortality of immigrants from wealthy countries residing in Spain
}

Enrique Regidor, Paloma Astasio, Paloma Ortega, David Martínez, M. Elisa Calle, Luis Fuente

\section{- To cite this version:}

Enrique Regidor, Paloma Astasio, Paloma Ortega, David Martínez, M. Elisa Calle, et al.. Healthy and unhealthy migrant effect on the mortality of immigrants from wealthy countries residing in Spain. European Journal of Epidemiology, 2010, 26 (4), pp.265-273. 10.1007/s10654-010-9511-z . hal00627545

\section{HAL Id: hal-00627545 \\ https://hal.science/hal-00627545}

Submitted on 29 Sep 2011

HAL is a multi-disciplinary open access archive for the deposit and dissemination of scientific research documents, whether they are published or not. The documents may come from teaching and research institutions in France or abroad, or from public or private research centers.
L'archive ouverte pluridisciplinaire HAL, est destinée au dépôt et à la diffusion de documents scientifiques de niveau recherche, publiés ou non, émanant des établissements d'enseignement et de recherche français ou étrangers, des laboratoires publics ou privés. 
Healthy and unhealthy migrant effect on the mortality of immigrants from wealthy countries residing in Spain

Enrique Regidor (1,2), Paloma Astasio (1), Paloma Ortega (1) David Martínez (1), M Elisa Calle (1) and Luis de la Fuente $(2,3)$

1. Department of Preventive Medicine and Public Health, Universidad Complutense de Madrid, Spain

2. CIBER Epidemiología y Salud Pública (CIBERESP). Spain

3. Plan Nacional de Sida, Instituto de Salud Carlos III, Madrid, Spain

\section{Author responsible for correspondence:}

Enrique Regidor

Department of Preventive Medicine and Public Health,

Universidad Complutense de Madrid

Ciudad Universitaria

28040 Madrid, Spain

Phone: +34 913941521

Fax: +34 913941803

email: enriqueregidor@hotmail.com 


\begin{abstract}
This study attempts to identify the possible existence of a healthy migrant effect and an unhealthy migrant effect on the mortality of immigrants from wealthy countries who move to Spain. Immigrants aged 35-64 years from France, Germany, Great Britain and 16 other wealthy OECD countries who resided in Spain were compared with respect to: 1) mortality from cancer, cardiovascular disease, and all other diseases and 2) employment status, duration of residence, and educational level, in two geographic areas: the "preferred destination area" -- the Mediterranean coast, Balearic Islands and Canary Islands -- and the rest of Spain. In general, cancer mortality was lower and mortality from cardiovascular disease was higher in immigrants who resided in the preferred destination area than in their countries of origin and than in immigrants who resided in the rest of Spain. Immigrants in the preferred destination area had a higher percentage of retired persons, longer time of residence and a lower percentage of persons with university education. The largest differences between the two areas in cardiovascular and all-disease mortality and in the frequency of the aforementioned sociodemographic characteristics were observed in British immigrants and those from the 16 OECD countries. Possible explanations for these findings are suggested which are compatible with the presence of an unhealthy and/or healthy immigrant bias in the two areas.
\end{abstract}

Key words: immigrants; wealthy countries; unhealthy migrant effect; healthy migrant effect; early retirement; Spain 


\section{Introduction}

Studies have shown important differences in the mortality of immigrants with respect to mortality in their destination countries, differences that vary in magnitude and direction depending on the immigrants' place of origin and cause of death. ${ }^{1-5}$ Various explanations for these results have been suggested, among them, characteristics of place or environment of origin, differences in genetic susceptibility, healthy migrant effect, time of residence in the host country, unhealthy re-migrant effect, differences in a wide variety of behavioural, cultural, socioeconomic and psychosocial characteristics, and adoption of the lifestyle in the host country. ${ }^{6-9}$

One aspect not considered to date in the study of immigrant mortality is the possibility of selfselection of sick individuals into migration. In wealthy countries many persons retire from the labour force because they develop diseases that make it impossible to work. ${ }^{10-11}$ Since this disability leads to reduced income, some people move to other countries where the cost of living is lower and the quality of life is similar to that of their country of origin. In these cases, any attempt to explain the mortality of immigrants from wealthy countries should consider the possibility that they are less healthy than the population in their country of origin.

Our hypothesis of an unhealthy migrant effect was motivated by our previous comparison of the mortality of immigrants residing in Spain with mortality in the Spanish population. We found that, in the early years of the present decade, mortality in immigrants aged 20-64 from western countries was $10 \%$ higher than mortality in the Spanish population (unpublished data). In contrast, a previous study conducted only in residents of the province of Madrid, located in the geographic centre of Spain, found that mortality in immigrants from western countries was $20 \%$ 
lower than mortality in the Madrid-born population. ${ }^{12}$ We then set ourselves the challenge of finding explanations for this paradox.

Spain has traditionally been one of the countries that offers the most attractions to persons in wealthy countries considering a change of residence. ${ }^{13}$ According to a recent study, Spain is the European country with the highest European Quality of Life Index due to low taxes, cheaper essential goods and a larger number of hours of sunshine. ${ }^{14-15}$ However, the primary attraction is not just any location in Spain, but is concentrated in the provinces of the Mediterranean coast, the Balearic Islands and the Canary Islands. ${ }^{16}$ Thus, the previously described finding of higher mortality in immigrants from wealthy countries than in the Spanish population may be due to higher mortality in immigrants who live in these areas than in immigrants who reside in the rest of Spain.

In this study, we attempt to obtain evidence to support the existence of a healthy migrant effect and an unhealthy migrant effect on mortality in immigrants from wealthy countries who move to Spain. For this purpose, we compare mortality in immigrants from wealthy countries who reside in two geographic areas -- the preferred destination area and the rest of Spain -- with mortality in the countries of origin, and we compare the frequency of various characteristics in immigrants who reside in each of these two areas of Spain.

\section{Methods}

Sources of data 
Mortality data by cause of death were obtained from the mortality register for 2002 to 2006, and population data were obtained from the population register for the same period. The data files from both registers were provided to the investigators by the National Institute of Statistics (NIS), which collects data on all deaths and demographic changes in the population. Information identifying individuals was eliminated to preserve confidentiality.

The mortality register includes province of residence, age, sex and birthplace of persons who die in Spain. These characteristics are collected by funeral directors based on information provided by relatives of the deceased. The records also include the underlying cause of death certified by a physician and coded according to the International Classification of Diseases, $10^{\text {th }}$ Revision. In the present study, external causes of death were excluded from the analysis because these are acute events. Besides deaths from all diseases, we also analysed deaths from cancer, from cardiovascular disease, and from all other diseases.

The population register includes information on all persons living in each municipality. The City Council is responsible for maintaining and updating the population register in each municipality. Each City Council reports to the NIS any changes in the data contained in this register. The NIS produces an annual file from the population register with reference to 1 January of each year, based on which official estimates are made of the population residing in Spain. These files were used in the present investigation. The variables contained in this file, obtained from the information provided by each resident, are province of residence, age, sex and birthplace.

This study was restricted to immigrants from OECD countries that had a higher per capita income than that of Spain between 1996 and 2006. Only immigrants aged 35-64 years were included. The upper limit was established because, based on our previous findings, our 
hypothesis refers to subjects of working age. And the lower limit was chosen because the probability of developing chronic diseases is very low in persons under 35 years of age.

Age, sex and birthplace were recorded in the same way in both files. Age was categorised in 10year age groups, and birthplace was defined as follows: based on the population size, only persons from France, Germany and the United Kingdom could be differentiated in separate groups, since they represent $70 \%$ of the immigrants from wealthy countries residing in Spain. The rest of the immigrants came from the following 16 countries: Switzerland, Italy, Belgium, The Netherlands, the United States of America, Sweden, Norway, Ireland, Denmark, Austria, Finland, Canada, Japan, Australia, Luxembourg and Iceland. Thus, the immigrants were grouped into four categories: those born in France, Germany, the United Kingdom and other OECD countries.

The National Survey of Immigrants, conducted between November 2006 and February 2007, was used to determine employment status, time of residence in Spain, and educational level of the immigrant population. The file with the survey microdata was downloaded from the NIS website. $^{17}$ The sample was designed so that the estimates would be representative of the immigrants from different countries, including the countries that were part of the European Union before its expansion in 2004, plus Switzerland and Norway, as well as the two countries of North America. For this purpose the sample was designed taking the 2006 population register as the reference. The sampling framework for this survey was the population aged 16 years and over born outside of Spain, who had resided in Spain for more than one year. The sample was selected in three stages: the first-stage units were the census sections stratified by municipal population size; the second-stage units were family households; and the third-stage units were household residents born outside of Spain. The non-response rate was 13\%, and the number of 
immigrants interviewed was 15,645. Participants in this survey were asked about their employment status in the week before the interview, the year they arrived in Spain, and the highest educational level completed.

\section{Statistical analysis}

A separate analysis was made for each of the two study areas: the preferred destination area and the rest of Spain (figure 1). The preferred destination area consisted of 12 of the 50 Spanish provinces, where $65 \%$ of the immigrants included in this study resided. These provinces were: Girona, Tarragona, Castellón, Alicante, Murcia, Almería, Granada, Málaga and Cádiz (located on the Mediterranean coast), The Balearic Islands, and the two provinces of the Canary Islands (Santa Cruz de Tenerife and Las Palmas). Although Barcelona and Valencia are located on the Mediterranean coast, they were included in the "rest of Spain" area because they have a high level of commercial and industrial development, and it is likely many immigrants live there for work-related reasons.

Men and women were analysed separately. We first calculated the age-adjusted mortality rate per 100,000 person-years in each immigrant group for the selected diseases. The age distribution of the Spanish population was used as the standard population. The mortality rate in the two study areas was then compared for each immigrant group. Specifically, we estimated the mortality rate ratios in residents of the preferred destination area with respect to residents in the rest of Spain. The confidence intervals for the mortality rate ratios were calculated from the variance estimated by the Mantel-Haenszel method for person-time data. ${ }^{18}$ 
To determine whether the mortality of immigrants residing in each study area is different from mortality in the countries of origin, we compared mortality from different causes of death in French, German and British citizens residing in the preferred destination area and in the rest of Spain with mortality in France, Germany and the United Kingdom in the period 2002-2006. Information on the deaths in those years and on the population aged 35-64 years from those countries was obtained from the mortality database of the World Health Organization. ${ }^{19}$ Mortality in the countries of origin of immigrants from "other OECD countries" was not estimated given that they comprise a heterogeneous group of subjects from many different countries.

In each immigrant group and destination area we also calculated the percentage of retired persons, the mean time of residence in Spain, and the percentage of persons with university education. Finally, we tested whether the magnitude of the mortality differences in the immigrant population with respect to mortality in the Spanish population varied depending on the area of residence. In each study area, we estimated the age- and sex-adjusted mortality rate ratios by birthplace, taking the mortality rate of persons born in Spain as the reference.

\section{Results}

Table 1 shows the population and number of deaths in immigrants residing in each study area, by place of birth. Most of the immigrants lived in the preferred destination area, except for the French immigrants who primarily resided in the rest of Spain. The mean age of immigrants in the 
preferred destination area was higher than in the rest of Spain: about 1.5 years higher in the French immigrants and 5-8 years in the other immigrant groups.

Table 2 presents the mortality rate ratios from the causes of death analysed in the preferred destination area with respect to the rest of Spain. Significant differences between the two areas for mortality from all diseases were seen only in British immigrants, whose mortality rate ratio was 1.44 (1.18 to 1.75$)$ in men and 1.36 (1.04 to 1.77) in women, and in immigrants from other OECD countries, whose mortality rate ratio was 1.43 (1.24 to 1.64$)$ in men and 1.52 (1.25 to 1.84) in women. In all immigrant groups the cancer mortality rate was lower in the preferred destination area than in the rest of Spain. In contrast, the cardiovascular disease mortality rate was higher in the preferred destination area than in the rest of Spain, except in French women. The largest differences were observed in British immigrants and those in other OECD countries, for whom the cardiovascular disease mortality rate ratio was 2.56 (95\% confidence interval 1.71 to 3.83 ) and 2.56 (1.92 to 3.41$)$ in men, and 4.32 (1.90 to 9.84) and 3.51 (2.08 to 5.91) in women, respectively. The highest mortality rate ratios for the rest of diseases were also observed in British immigrants and those from other OECD countries.

Table 3 presents the age-adjusted mortality rates and the mortality rate ratios for the causes of death analysed in each area and in the country of origin. In general, mortality rate ratios for cardiovascular diseases were significantly higher and mortality rate ratios for cancer were significantly lower in immigrants residing in the preferred destination area than in the country of origin. Likewise, the mortality rate ratios for cardiovascular diseases in British immigrants residing in the rest of Spain were lower than in the UK. With respect to mortality from the rest of diseases, French immigrants had lower mortality in the two study areas than in France, whereas 
British men residing in the preferred destination area had a higher mortality rate ratio than in the UK.

Immigrants in the preferred destination area had a higher percentage of retired persons and a lower percentage of persons with university education - except in German women - than those in the rest of Spain (table 4). The largest differences between the two areas were seen in British immigrants and those from other OECD countries. Immigrants residing in the preferred destination area had lived in Spain a shorter time, with the largest difference between the two areas seen in British immigrants.

The mortality rate ratios in each immigrant group with respect to the Spanish population are presented in table 5. In all four immigrant groups the magnitude of the mortality rate ratios for cancer and cardiovascular disease was different in the two study areas; in contrast, the magnitude of the mortality rate ratios for the rest of diseases in the two areas was only clearly different in British immigrants and those from other OECD countries. The mortality rate ratios for all diseases were similar for French and German immigrants in the two study areas, and did not differ significantly with respect to the Spanish population. However, in British immigrants and those from other OECD countries these mortality rate ratios were, respectively, 1.14 (1.04 to $1.25)$ and 1.19 (1.07 to 1.32$)$ in the preferred destination area, and 0.86 (0.64 to 1.16$)$ and 0.86 (0.70 to 1.05$)$ in the rest of Spain.

\section{Discussion}


Our comparison of mortality in immigrants from wealthy countries in the two study areas with mortality in their countries of origin yields the following three relevant findings: a) mortality from cancer is lower in the preferred destination area and in the countries of origin than in the rest of Spain; b) except in French women, mortality from cardiovascular disease is higher in the preferred destination area and in the countries of origin than in the rest of Spain; and c) in British immigrants and those from other OECD countries mortality from the rest of diseases is higher in the preferred destination area than in the rest of Spain. Because the largest differences between the two areas of Spain in mortality from cardiovascular disease and from the rest of diseases are seen in British immigrants and those from other OECD countries, mortality for all diseases in these immigrants is between $36 \%$ and $52 \%$ higher in the preferred destination area than in the rest of Spain. The comparison of immigrant mortality with mortality in the Spanish population also reflects these findings.

Several studies have shown that early retirement is associated with increased mortality. ${ }^{20-22}$ Some authors have noted that mortality from cardiovascular disease associated with early retirement may also be attributed to changes after retirement - reduced income, abandoning healthy habits, or psychological consequences - that increase the risk of developing these diseases. ${ }^{23}$ We found that immigrants residing in the preferred destination area had a higher proportion of retired people than immigrants residing in the rest of Spain. This could explain why mortality from cardiovascular disease was higher in the preferred destination area in most immigrants than in the rest of Spain and in their countries of origin.

Increased mortality associated with early retirement has also been attributed to illness and poor health before retirement. ${ }^{20-22,24-25}$ Both cardiovascular disease and the rest of diseases digestive, respiratory, metabolic, renal - that constitute the leading causes of death are chronic 
diseases that generally have a prolonged natural history before retirement. Thus, the higher mortality from these causes of death in the preferred destination area suggests poor health before retirement and, consequently, a possible unhealthy immigrant bias in mortality in this area. The fact that the elevated mortality rate ratio for the rest of diseases by area of residence was only observed in British immigrants and those from other OECD countries may be due to the large proportion of retired persons in these two immigrant groups in the preferred destination area.

In any case, it can not be ruled out that the elevated differences in mortality from cardiovascular disease and the rest of diseases in British immigrants and those from other OECD countries who reside in the preferred destination area and in the rest of Spain may be due to the presence of a healthy immigrant bias in the rest of Spain. Mortality from both causes of death in the United Kingdom was found to be much higher than that seen in British immigrants in the rest of Spain.

Likewise, we also can not rule out the possible influence of immigrants' educational level on the mortality from cardiovascular disease and the rest of diseases observed in British immigrants and those from other OECD countries who reside in the rest of Spain. Given the strong association between educational level and mortality from both causes of death, ${ }^{26-28}$ this low mortality may be due to the high educational level in British immigrants and those from other OECD countries, about half of whom had university education. These may be persons who have moved to Spain to continue their careers. This fact would help explain the large differences in cardiovascular mortality observed between the two areas in these immigrants.

Cancer also constitutes a collection of chronic processes, but the pattern of cancer mortality is different from the pattern seen in the other diseases. Various explanations can be suggested for this finding. One of them is related with the large proportion of retired people among immigrants 
residing in the preferred destination area. The probability of moving after early retirement may be lower if a person has been diagnosed with cancer than in the case of another disease. Since the prognosis for cancer is worse than for other diseases, people may wish to die in their country of origin. Another explanation may be that immigrants frequently return to their country of birth if they are diagnosed with cancer, but not if they are diagnosed with another disease. Nevertheless, it is unlikely that some immigrants - such as the British - would have developed cancer after emigrating to the preferred destination area given that, on average, they had lived in Spain for quite a short time. Moreover, this explanation would entail the assumption that immigrants who reside in the rest of Spain do not return to their country of origin as a result of developing cancer. And, finally, we can not rule out the possible existence of a healthy immigrant bias in relation to this disease in the preferred destination area. However, this would not explain why this bias is not observed in mortality from cancer in immigrants residing in the rest of Spain.

Mortality from the rest of diseases in immigrants from France and Germany was similar in both the preferred destination area and the rest of Spain. However, the reason for this finding was different in these two immigrant groups. Whereas a healthy immigrant bias was observed in the French immigrants, since mortality in both areas was lower than mortality in France, no significant differences in mortality were seen in German immigrants in the two areas in comparison to mortality in Germany.

In interpreting our study findings we must consider the possibility of a numerator/denominator information bias in relation with the country of birth, since the population data and mortality data were taken from different sources. However, the probability of this bias is small since the source of the population data is a continually updated register that receives data from the mortality register. Likewise, mortality rates could have been overestimated since not all immigrants in 
Spain are necessarily inscribed in the population register, and this overestimate could be greater in the preferred destination area. However, the possible influence of this bias on our findings is negligible, since it would not explain why the pattern of cancer mortality differs from that observed for cardiovascular mortality. On the other hand, neither the mortality register nor the population register includes information about employment status, educational level or time of residence in Spain. However, the effect of these factors on the results could only be evaluated indirectly, from the information provided by the National Survey of Immigrants.

In summary, immigrants from wealthy countries who reside in the preferred destination area, which consists of the Mediterranean coast, the Balearic Islands and the Canary Islands, have lower mortality from cancer and higher mortality from diseases other than cancer than those who reside in the rest of Spain and than in their countries of origin. These findings are compatible with the presence of an unhealthy and healthy immigrant bias in the two areas. We have suggested possible explanations here, but follow-up studies that permit estimation of mortality in both the migrant population and the population that remains in the places of origin will be needed to determine the reasons for these findings. 


\section{References}

1. Wild S, McKeigue P. Cross sectional analysis of mortality by country of birth in England and Wales. BMJ 1997; 314: 705-10.

2. Singh GK, Siahpush M. All-cause and cause-specific mortality of immigrants and native born in the United States. Am J Public Health 2001; 91: 392-399.

3. Bos V, Kunst AE, Keij-Deerenberg IM, Garssen J, Mackenbach J. Ethnic inequalities in age- and cause-specific mortality in The Netherlands. Int J Epidemiol 2004; 3: 1112 1119.

4. Deboosere P, Gadeyne S. Adult migrant mortality advantage in Belgium: evidence using census and register data. Population 2005; 60: 655-698.

5. Gadd M, Johanson S-E, Sundquist J, Wändell P. Are there differences in all-cause and coronary heart disease mortality between immigrants in Sweden and in their country of birth? A follow-up study of total populations. BMC Public Health 2006; 6: 102.

6. Abraido-Lanza AF, Dohrenwent BP, Ng-Mak DS, Turner JB. The Latino mortality paradox: a test of the "salmon bias" and healthy migrant hypothesis. Am J Public Health 1999; 89: 1543-8.

7. Razum O, Zeeb H, Rohrmann S. The "healthy migrant effect" - not merely a fallacy of inaccurate denominator figures. Int J Epidemiology 2000; 29: 191-2. 
8. Davey Simth G, Chaturvedi N, Harding S, Nazroo J, Williams R. Ethnic inequalities in health: a review of UK epidemiological evidence. Critical Public Health 2000; 10: 375408.

9. Razum O. Commentary: of salmon and time travellers -musing on the mystery of migrant mortality. Int J Epidemiol 2006; 35: 919-21.

10. O'Reilly K. Intra-European migration and the mobility-enclosure dialectic. Sociology 2007; 41: 277-293.

11. Warnes AM, Friedrich K, Kellaher L, Torres S. The diversity and welfare of older migrants in Europe. Ageing Soc 2004; 24: 307-326.

12. Regidor E, de la Fuente L, Martínez D, Calle ME, Domínguez V. Heterogeneity in cause-specific mortality according to birthplace in immigrant men residing in Madrid, Spain. Ann Epidemiol 2008; 18: 605-615.

13. Rodríguez V, Fernández-Mayorales G, Rojo F. European retirees on the Costa del Sol: a cross-national comparison. Int J Popul Geogr. 1998; 4: 183-200.

14. Casado-Díaz MA, Kaiser C, Warnes AM. Northern European retired residents in nine southern European areas: characteristics motivations and adjustment. Ageing Soc 2004; 24: $353-381$. 
15. UK and Ireland rank bottom in Quality of Life Index www.uswitch.com/PressRoom/Index.aspx?downloadfile=UK-AND-IRELAND-RANK-BOTTOM-INEUROPEAN-QUALITY-OF-LIFE-INDEX (accessed 2 January 2009)

16. Instituto Nacional de Estadística. Statistical exploitation of the Municipal Register http://www.ine.es/jaxi/menu.do?type=pcaxis\&path=\%2Ft20/e245\&file=inebase $\& \mathrm{~L}=1$ (accessed 2 January 2009).

17. Instituto Nacional de Estadística National Immigrant Survey 2007 http://www.ine.es/jaxi/menu.do?type=pcaxis\&path=\%2Ft20\%2Fp319\&file=inebase $\& \mathrm{~L}$ $=1$ (accessed 1 July 2010).

18. Greenland S, Rothman KJ. Introduction to stratified analysis. In: Rothman KJ, Greenland S (eds). Modern Epidemiology. Philadelphia: Lippincott Williams \& Wilkins, 1998:253-280.

19. World Health Organization. Health statistics and health information systems. WHO Mortality Database: http://www.who.int/whosis/database/mort/table1.cfm (accessed 5 Jul 2010).

20. Morris JK, Cook DG, Gerald Shaper A. Loss of employment and mortality. BMJ 1994; 308: 1135-9. 
21. Quaade T, Engholm G, Johansen AMT, Moller H. Mortality in relation to early retirement in Denmark: a population-based study. Scand J Public Health 2002; 30: 216222.

22. Tsai AP, Wendt JK, Donnelly RP, de Jong G, Ahmed FS. Age at retirement and long term survival of an industrial population: prospective cohort study. BMJ 2005; 331: 995.

23. Bamia C, Trichopoulou A, Trichopoulos D. Age at retirement and mortality in a general population sample: the Greek EPIC Study. Am J Epidemiol 2007; 167: 561569.

24. Karpansalo M, Manninen P, Kauhanen J, Lakka TA, Salonen JT. Perceived health as a predictor of early retirement. Scan J Work Environ Health 2004; 30: 287-292.

25. Mein G, Martikainen P, Stansfeld SA, Brunner EJ, Fuhrer R, Marmot MG. Predictor of early retirement in British civil servants. Age Ageing 2000; 29: 529-536.

26. Kaplan GA, Keil JEK. Socioeconomic factors and cardiovascular disease: a review of the literature. Circulation 1993; 88: 1973-1998.

27. G Davey Smith G, Hart C, Hole D, MacKinnon P, Gillis C, Watt G, Blane D, Hawthorne V. Education and occupational social class: which is the more important indicator of mortality risk? J Epidemiol Community Health 1998; 52: 153-160. 
28. Huisman M, Kunst E, Bopp M, Borgan JK, Borrell C, Costa G, Deboosere P, Gadeyne S, Glickman M, Marianacci CH, Minder CH, Regidor E, Valkonen T, Mackenbach JP. Educational inequalities in cause-specific mortality in middle-aged and older men and women in eight western European populations. Lancet 2005, 365. 493-500. 
Figure 1. Spanish provinces included in each study area: Preferred destination area and rest of Spain.

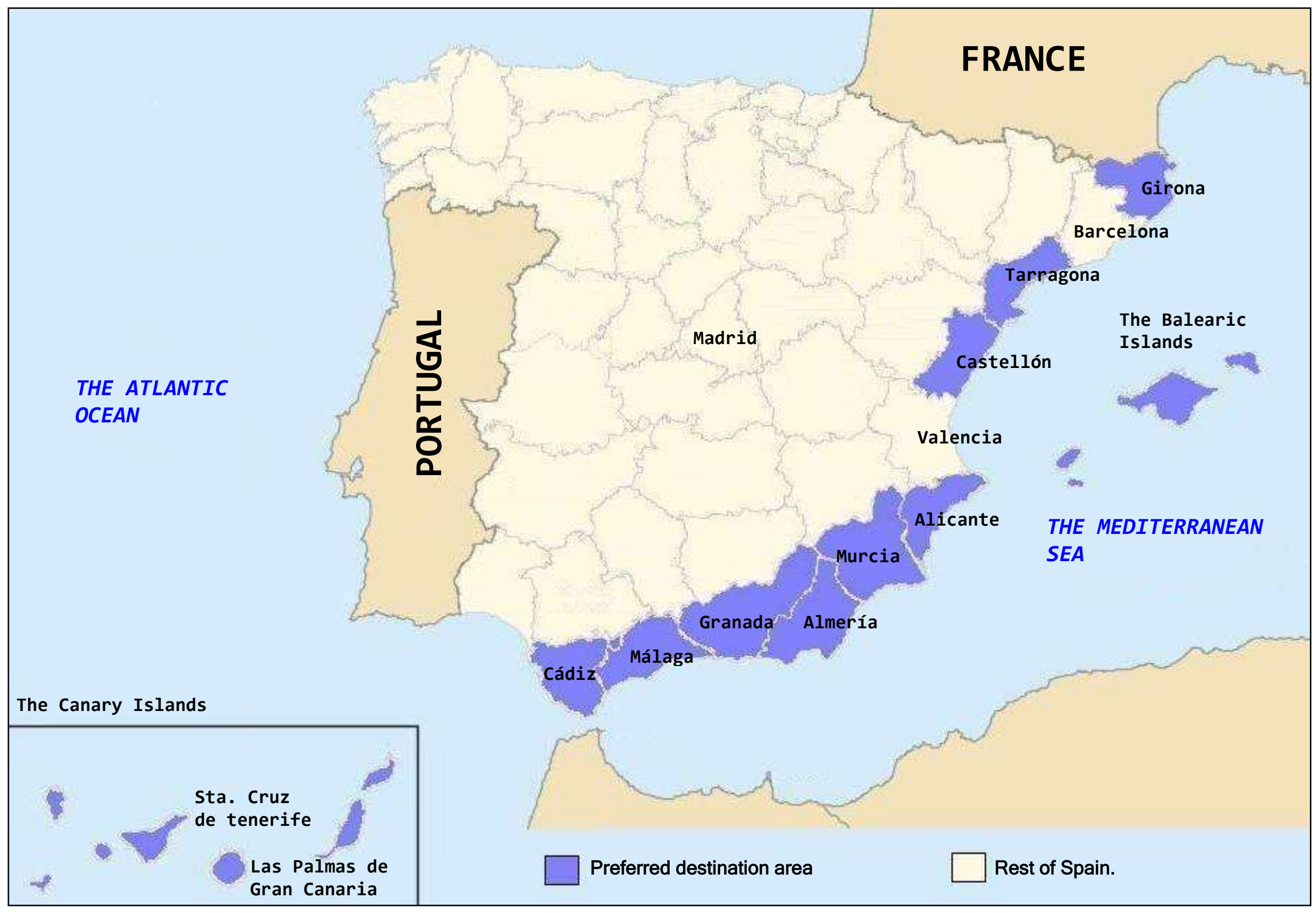


Table 1. Population and deaths in immigrants aged 35-64 residing in the two study areas, by birthplace. Spain 2002-2006

\begin{tabular}{|c|c|c|c|c|c|c|}
\hline \multirow[t]{2}{*}{ Birthplace } & \multicolumn{3}{|c|}{ 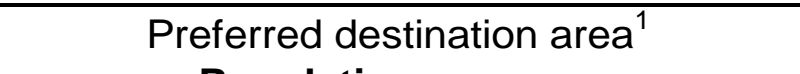 } & \multicolumn{2}{|c|}{$\begin{array}{l}\text { Rest of Spain } \\
\text { Population }\end{array}$} & \multirow{2}{*}{ Deaths } \\
\hline & Person-years & Mean age & Deaths & Person-years & Mean age & \\
\hline \multicolumn{7}{|l|}{ Men } \\
\hline France & 74,721 & 43.9 & 201 & 119,372 & 42.4 & 256 \\
\hline Germany & 150,164 & 50.8 & 836 & 69,906 & 42.3 & 164 \\
\hline United Kingdom & 209,561 & 52.2 & 1,259 & 44,805 & 45.6 & 110 \\
\hline Other OECD countries ${ }^{2}$ & 172,701 & 49.9 & 901 & 122,430 & 44.3 & 286 \\
\hline \multicolumn{7}{|l|}{ Women } \\
\hline France & 81,364 & 44.7 & 106 & 134,603 & 43.5 & 157 \\
\hline Germany & 163,477 & 50.6 & 403 & 71,199 & 43.4 & 120 \\
\hline United Kingdom & 235,983 & 51.8 & 694 & 41,821 & 46.6 & 62 \\
\hline Other OECD countries ${ }^{2}$ & 176,205 & 50.2 & 550 & 107,455 & 45.0 & 148 \\
\hline
\end{tabular}

1. The Mediterranean coast, The Balearic Islands and The Canary Islands

2. Switzerland, Italy, Belgium, The Netherlands, the United States of America, Sweden, Norway, Ireland, Denmark, Austria, Finland, Canada, Japan, Australia, Luxembourg and Iceland 
Table 2. Number of deaths, and mortality rate ratios with $95 \%$ confidence intervals $(95 \% \mathrm{Cl})$ in immigrants aged $35-64$ residing in the two study areas, by sex, cause of death, and birthplace. Spain 2002-2006

\begin{tabular}{|c|c|c|c|c|c|c|c|c|}
\hline \multirow[b]{3}{*}{$\begin{array}{l}\text { Cause of death }{ }^{1} \text { and } \\
\text { birthplace }\end{array}$} & \multicolumn{4}{|c|}{ Men } & \multicolumn{4}{|c|}{ Women } \\
\hline & \multicolumn{2}{|c|}{ Deaths } & \multirow{2}{*}{\multicolumn{2}{|c|}{$\begin{array}{l}\text { Mortality rate ratio }(95 \% \\
\mathrm{Cl})\end{array}$}} & \multicolumn{2}{|c|}{ Deaths } & \multirow{2}{*}{\multicolumn{2}{|c|}{$\begin{array}{l}\text { Mortality rate ratio (95\% } \\
\qquad \mathrm{Cl})\end{array}$}} \\
\hline & $\begin{array}{c}\text { Preferred } \\
\text { destination } \\
\text { area } \\
\end{array}$ & $\begin{array}{l}\text { Rest of } \\
\text { Spain }\end{array}$ & & & $\begin{array}{c}\text { Preferred } \\
\text { destination } \\
\text { area }\end{array}$ & $\begin{array}{l}\text { Rest of } \\
\text { Spain }\end{array}$ & & \\
\hline \multicolumn{9}{|l|}{ All diseases } \\
\hline France & 201 & 256 & 0.98 & $(0.80-1.22)$ & 106 & 157 & 1.00 & $(0.77-1.31)$ \\
\hline Germany & 836 & 164 & 1.13 & $(0.93-1.37)$ & 403 & 120 & 0.82 & $(0.66-1.03)$ \\
\hline United Kingdom & 1,259 & 110 & 1.44 & $(1.18-1.75)$ & 694 & 62 & 1.36 & $(1.04-1.77)$ \\
\hline Other OECD countries & 901 & 286 & 1.43 & $(1.24-1.64)$ & 550 & 148 & 1.52 & $(1.52-1.84)$ \\
\hline \multicolumn{9}{|l|}{ Cancer } \\
\hline France & 67 & 113 & 0.64 & $(0.46-0.89)$ & 54 & 88 & 0.91 & $(0.63-1.32)$ \\
\hline Germany & 176 & 54 & 0.61 & $(0.43-0.85)$ & 163 & 63 & 0.64 & $(0.47-0.88)$ \\
\hline United Kingdom & 348 & 47 & 0.82 & $(0.60-1.12)$ & 258 & 43 & 0.70 & $(0.51-0.98)$ \\
\hline Other OECD countries & 220 & 122 & 0.73 & $(0.58-0.92)$ & 230 & 92 & 0.98 & $(0.76-1.26)$ \\
\hline \multicolumn{9}{|c|}{ Cardiovascular diseases } \\
\hline France & 64 & 46 & 1.86 & $(1.21-2.86)$ & 14 & 25 & 0.86 & $(0.43-1.73)$ \\
\hline Germany & 388 & 44 & 1.71 & $(1.20-2.44)$ & 115 & 20 & 1.25 & $(0.75-2.08)$ \\
\hline United Kingdom & 538 & 26 & 2.56 & $(1.71-3.83)$ & 209 & 6 & 4.32 & $(1.90-9.84)$ \\
\hline Other OECD countries & 369 & 60 & 2.56 & $(1.92-3.41)$ & 148 & 17 & 3.51 & $(2.08-5.91)$ \\
\hline \multicolumn{9}{|l|}{ Rest of diseases } \\
\hline France & 70 & 97 & 1.07 & $(0.73-1.56)$ & 38 & 44 & 1.28 & $(0.79-2.07)$ \\
\hline Germany & 272 & 66 & 1.22 & $(0.88-1.70)$ & 125 & 37 & 0.89 & $(0.58-1.35)$ \\
\hline United Kingdom & 373 & 37 & 1.44 & $(1.01-2.04)$ & 227 & 13 & 2.19 & $(1.24-3.86)$ \\
\hline Other OECD countries & 312 & 104 & 1.65 & $(1.30-2.11)$ & 172 & 39 & 1.98 & $(1.37-2.86)$ \\
\hline
\end{tabular}

1. Codes of the International Classification of Diseases, 10th Revision: C00 to C97 (cancer), I00 to 199 (cardiovascular diseases), and rest of codes from A00 to R99 (rest of diseases). 
Table 3. Age-adjusted mortality rate per 100,000 persons-years, and mortality rate ratios with $95 \%$ confidence intervals $(95 \% \mathrm{Cl})$ in immigrants resident in the two areas of Spain and in resident population in the county of birth, by age and cause of death, 2002-2006

\begin{tabular}{|c|c|c|c|c|c|c|}
\hline $\begin{array}{l}\text { Cause of death }{ }^{1} \text { and } \\
\text { birthplace }\end{array}$ & $\begin{array}{l}\text { Preferred } \\
\text { destination } \\
\text { area }\end{array}$ & $\begin{array}{l}\text { Country } \\
\text { of birth }\end{array}$ & $\begin{array}{l}\text { Rest of } \\
\text { Spain }\end{array}$ & $\begin{array}{c}\text { Preferred } \\
\text { destination area }\end{array}$ & $\begin{array}{l}\text { Country } \\
\text { of birth }\end{array}$ & Rest of Spain \\
\hline & & Rate & & Mortality & rate ratio & $(95 \% \mathrm{Cl})$ \\
\hline \multicolumn{3}{|l|}{ All diseases } & & & & \\
\hline France & 385.8 & 519.5 & 392.1 & $0.74(0,64,0,87)$ & 1.00 & $0.75(0.65,0.87)$ \\
\hline Germany & 482.8 & 497.0 & 426.3 & $0.97(0.90,1.04)$ & 1.00 & $0.86(0.72,1.03)$ \\
\hline United Kingdom & 482.3 & 430.9 & 335.8 & $1.12(1.05,1.19)$ & 1.00 & $0.78(0.64,0.94)$ \\
\hline Other OECD countries & 473.2 & .. & 331.6 & $\ldots$ & . & . \\
\hline \multicolumn{7}{|l|}{ Cancer } \\
\hline France & 134.8 & 226.5 & 212.2 & $0.59(0.46,0.77)$ & 1.00 & $0.94(0.76,1.15)$ \\
\hline Germany & 98.8 & 177.3 & 163.0 & $0.56(0.48,0.65)$ & 1.00 & $0.92(0.68,1.24)$ \\
\hline United Kingdom & 119.5 & 150.1 & 146.2 & $0.80(0.71,0.89)$ & 1.00 & $0.97(0.73,1.30)$ \\
\hline Other OECD countries & 113.1 & .. & 154.4 & . & . & $\cdots$ \\
\hline \multicolumn{7}{|l|}{ Cardiovascular diseases } \\
\hline France & 138.0 & 91.6 & 74.1 & $1.51(1.16,1.96)$ & 1.00 & $0.81(0.57,1.14)$ \\
\hline Germany & 217.0 & 142.7 & 126.6 & $1.52(1.37,1.69)$ & 1.00 & $0.89(0.63,1.24)$ \\
\hline United Kingdom & 205.0 & 142.6 & 80.0 & $1.44(1.31,1.58)$ & 1.00 & $0.56(0.38,0.83)$ \\
\hline Other OECD countries & 189.3 &.. & 74.0 & . & . & . \\
\hline \multicolumn{7}{|l|}{ Rest of diseases } \\
\hline France & 113.0 & 201.3 & 105.7 & $0.56 \quad(0.43,0.79)$ & 1.00 & $0.52(0.40,0.68)$ \\
\hline Germany & 167.0 & 176.9 & 136.7 & $0.94 \quad(0.83,2.07)$ & 1.00 & $0.77(0.57,1.05)$ \\
\hline United Kingdom & 157.7 & 138.2 & 109.7 & $1.14 \quad(1.02,1.27)$ & 1.00 & $0.79(0.57,1.11)$ \\
\hline Other OECD countries & 170.8 &.. & 103.2 & $\ldots$ & . & $\ldots$ \\
\hline \multicolumn{7}{|l|}{ WOMEN } \\
\hline \multicolumn{7}{|l|}{ All diseases } \\
\hline France & 179.0 & 232.3 & 178.4 & $0.77(0,63,0,94)$ & 1.00 & $0.77(0.64,0.92)$ \\
\hline Germany & 223.1 & 253.9 & 270.7 & $0.88(0.79,0.97)$ & 1.00 & $1.09(0.87,1.30)$ \\
\hline United Kingdom & 238.0 & 275.1 & 175.0 & $0.86(0.80,0.99)$ & 1.00 & $0.64(0.49,0.82)$ \\
\hline Other OECD countries & 275.3 & .. & 180.7 & . & . & $\cdots$ \\
\hline \multicolumn{7}{|l|}{ Cancer } \\
\hline France & 92.8 & 121.8 & 101.4 & $0.76(0.57,1.01)$ & 1.00 & $0.83(0.66,1.05)$ \\
\hline Germany & 90.5 & 129.7 & 141.1 & $0.70(0.59,0.82)$ & 1.00 & $1.09(0.83,1.43)$ \\
\hline United Kingdom & 85.7 & 139.9 & 121.8 & $0.61(0.54,0.70)$ & 1.00 & $0.87(0.64,1.18)$ \\
\hline Other OECD countries & 113.4 &.. & 115.4 & . & . & . \\
\hline \multicolumn{7}{|l|}{ Cardiovascular diseases } \\
\hline France & 25.1 & 28.4 & 29.3 & $0.88(0.51,1.53)$ & 1.00 & $1.02(0.66,1.59)$ \\
\hline Germany & 60.6 & 49.4 & 48.7 & $1.22(1.01,1.48)$ & 1.00 & $0.98(0.61,1.58)$ \\
\hline United Kingdom & 72.2 & 53.7 & 16.7 & $1.34(1.16,1.55)$ & 1.00 & $0.31(0.14,0.70)$ \\
\hline Other OECD countries & 74.7 & .. & 21.3 & . & . & . \\
\hline \multicolumn{7}{|l|}{ Rest of diseases } \\
\hline France & 61.1 & 82.1 & 47.7 & $0.74 \quad(0.53,1.05)$ & 1.00 & $0.58(0.42,0.81)$ \\
\hline Germany & 72.0 & 74.6 & 81.0 & $0.96(0.80,1.16)$ & 1.00 & $1.08(0.74,1.59)$ \\
\hline United Kingdom & 80.1 & 81.4 & 36.6 & $0.98(0.86,1.13)$ & 1.00 & $0.45(0.26,0.78)$ \\
\hline Other OECD countries & 87.2 & .. & 44.0 & 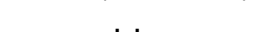 & . & . \\
\hline
\end{tabular}

1. Codes of the International Classification of Diseases, 10th Revision: A00-R99 (all diseases), C00 to C97 (cancer), I00 to 199 (cardiovascular diseases), and rest of codes from A00 to R99 (rest of diseases). 
Table 4. Sample size and population characteristics of immigrants aged 35-64 residing in the two study areas, by sex and birthplace. Spain 2006

\begin{tabular}{|c|c|c|c|c|c|c|}
\hline \multirow[b]{2}{*}{ Birthplace } & \multicolumn{3}{|c|}{ Men } & \multicolumn{3}{|c|}{ Women } \\
\hline & $\begin{array}{c}\text { Preferred } \\
\text { destination } \\
\text { area } \\
\end{array}$ & $\begin{array}{l}\text { Rest of } \\
\text { Spain }\end{array}$ & Difference & $\begin{array}{c}\text { Preferred } \\
\text { destination } \\
\text { area } \\
\end{array}$ & $\begin{array}{l}\text { Rest of } \\
\text { Spain }\end{array}$ & Difference \\
\hline & \multicolumn{6}{|c|}{ Sample size } \\
\hline France & 94 & 121 & .. & 88 & 122 & .. \\
\hline Germany & 73 & 54 & .. & 100 & 62 & .. \\
\hline United Kingdom & 235 & 66 & .. & 231 & 36 & .. \\
\hline \multirow[t]{2}{*}{ Other OECD countries } & 128 & 133 & .. & 149 & 105 & .. \\
\hline & \multicolumn{6}{|c|}{ Percentage of retired population } \\
\hline France & 8.1 & 1.9 & 6.2 & 7.0 & 1.8 & 5.2 \\
\hline Germany & 9.9 & 5.8 & 4.1 & 18.7 & 0.0 & 18.7 \\
\hline United Kingdom & 43.9 & 5.0 & 38.9 & 44.0 & 3.1 & 40.9 \\
\hline \multirow[t]{2}{*}{ Other OECD countries } & 23.3 & 3.1 & 20.2 & 25.0 & 1.4 & 23.6 \\
\hline & \multicolumn{6}{|c|}{ Percentage of population with university education } \\
\hline France & 22.7 & 26.8 & -4.1 & 32.0 & 35.1 & -3.1 \\
\hline Germany & 30.7 & 42.0 & -11.3 & 31.4 & 30.1 & 1.3 \\
\hline United Kingdom & 30.6 & 61.6 & -31.0 & 17.2 & 45.2 & -28.0 \\
\hline \multirow[t]{2}{*}{ Other OECD countries } & 26.1 & 47.6 & -21.5 & 29.5 & 45.5 & -16.0 \\
\hline & \multicolumn{6}{|c|}{ Mean time of residence in Spain (in years) } \\
\hline France & 21.4 & 26.2 & -4.8 & 24.0 & 29.1 & -5.1 \\
\hline Germany & 14.2 & 22.1 & -7.9 & 15.9 & 25.1 & -9.2 \\
\hline United Kingdom & 5.5 & 17.4 & -11.9 & 8.1 & 22.4 & -14.3 \\
\hline Other OECD countries & 10.9 & 19.0 & -8.1 & 13.8 & 23.4 & -9.6 \\
\hline
\end{tabular}


Table 5. Sex- and age-adjusted mortality rate per 100,000 persons-years in persons born in Spain and mortality rate ratios with $95 \%$ confidence intervals ( $95 \% \mathrm{Cl}$ ) by cause of death in immigrants vs. persons born in Spain in each study area. Spain 2002-2006

\begin{tabular}{|c|c|c|c|c|c|c|}
\hline \multirow{2}{*}{$\begin{array}{l}\text { Cause of death }{ }^{1} \text { and area of } \\
\text { residence }\end{array}$} & \multirow{2}{*}{$\begin{array}{l}\text { Mortality rate } \\
\text { in persons } \\
\text { born in Spain }\end{array}$} & \multicolumn{5}{|c|}{ Mortality rate ratios ( $95 \% \mathrm{Cl}$ ) by birthplace } \\
\hline & & Spain & France & Germany & United Kingdom & $\begin{array}{l}\text { Other OECD } \\
\text { countries }\end{array}$ \\
\hline \multicolumn{7}{|l|}{ All diseases } \\
\hline Preferred destination area & 194.5 & 1.00 & $0.91(0.72-1.16)$ & $1.11(0.98-1.25)$ & $1.14(1.04-1.25)$ & $1.19(1.07-1.32)$ \\
\hline Rest of Spain & 187.5 & 1.00 & $0.96(0.78-1.18)$ & $1.15(0.90-1.48)$ & $0.86(0.64-1.16)$ & $0.86(0.70-1.05)$ \\
\hline \multicolumn{7}{|l|}{ Cancer } \\
\hline Preferred destination area & 94.3 & 1.00 & $0.76(0.54-1.07)$ & $0.61(0.50-0.74)$ & $0.67(0.57-0.78)$ & $0.74(0.63-0.87)$ \\
\hline Rest of Spain & 96.2 & 1.00 & $1.01(0.77-1.34)$ & $0.96(0.68-1.36)$ & $0.88(0.61-1.28)$ & $0.88(0.68-1.13)$ \\
\hline \multicolumn{7}{|l|}{ Cardiovascular diseases } \\
\hline Preferred destination area & 44.5 & 1.00 & $1.17(0.64-2.15)$ & $1.91(1.53-2.38)$ & $1.91(1.61-2.26)$ & $1.81(1.50-2.20)$ \\
\hline Rest of Spain & 39.3 & 1.00 & $0.84(0.50-1.42)$ & $1.42(0.81-2.48)$ & $0.80(0.33-1.93)$ & $0.78(0.45-1.34)$ \\
\hline \multicolumn{7}{|l|}{ Rest of diseases } \\
\hline Preferred destination area & 55.7 & 1.00 & $0.97(0.64-1.46)$ & $1.31(1.05-1.62)$ & $1.33(1.12-1.57)$ & $1.44(1.20-1.73)$ \\
\hline Rest of Spain & 51.0 & 1.00 & $0.94\left(\begin{array}{ll}0.63 & 1.40\end{array}\right)$ & $1.31(0.83-2.07)$ & $0.88(0.47-1.65)$ & $0.89(0.60-1.31)$ \\
\hline
\end{tabular}

1. Codes of the International Classification of Diseases, 10th Revision: A00 to R99 (all diseases), C00 to C97 (cancer), 100 to 199 (cardiovascular diseases), rest of codes A00 to R99 (rest of diseases). 